\title{
PERTUMBUHAN DAN KELANGSUNGAN HIDUP BENIH IKAN NILA (Oreochromis niloticus) DENGAN DOSIS VITAMIN MIX YANG BERBEDA
}

\author{
Growth and Survival Rate Tilapia (Oreochromis niloticus) with Different Doses of Vitamin Mix
}

\author{
Siti Aidia Mutia ${ }^{1}$, Siswanta Kaban ${ }^{2}$, dan Sumantriyadi ${ }^{1}$ \\ 1) Balai Karantina Ikan, Pengendalian Mutu dan Keamanan Hasil Perikanan Palembang \\ 2) Balai Riset Penelitian Perairan Umum Daratan dan Penyuluh Perikanan Palembang \\ 3) Program Studi Perikanan Fakultas Perikanan Universitas PGRI Palembang \\ Email : sumantriyadi@ymail.com
}

\begin{abstract}
Abstrak
Penelitian ini mengenai Pertumbuhan dan Sintasan Benih Ikan Nila dengan Dosis Vitamin Mix Yang Berbeda. Penelitian dilaksanakan bertempat di Kelompok Tani Tambak Mulia, Kota Palembang. Metode penelitian yang digunakan yaitu Rancangan Acak Lengkap (RAL) dengan 4 perlakuan dan 3 ulangan. Hasil penelitian menunjukkan bahwa perlakuan D (penambahan Vitamin mix sebesar $3 \%$ dari jumlah pakan) dipilih sebagai perlakuan terbaik dibandingkan perlakuan lainya. Pada perlakuan D memberikan pertambahan pertumbuhan dan sintasan terbaik yaitu panjang mutlak sebesar $5,77 \mathrm{~cm}$ dengan berat sebesar 19,48 gr dan nilai SR sebesar 86,67 \%. Untuk perlakuan C pertambahan pertumbuhan panjang mutlak sebesar 5,49 cm dengan berat 17,64 gr dan nilai SR sebesar $80 \%$. Perlakuan B pertambahan pertumbuhan panjang mutlak sebesar $5,20 \mathrm{~cm}$ dengan berat $15,35 \mathrm{gr}$ dan nilai SR sebesar $76,67 \%$. Sedangkan perlakuan A memberikan pertambahan pertumbuhan terendah yaitu panjang mutlak sebesar $5,01 \mathrm{~cm}$ dengan berat sebesar 15,03 gr dan nilai SR sebesar 76,67 \%. Parameter kualitas air yang diukur selama penelitian masih dalam batas toleransi untuk tumbuh dan berkembang benih Ikan Nila. Dari hasil penelitian yang dilakukan untuk penambahan vitamin mix pada pakan sebaiknya menggunakan dosis 3 $\%$, karena memberikan pertumbuhan dan sintasan yang terbaik.
\end{abstract}

Kata Kunci: Ikan nila, Kandungan Gizi, Vitamin Mix

\begin{abstract}
The research on the Growth and Survival Seed Tilapia with Different Doses of Vitamin Mix. The experiment was conducted in kelompok Tani Tambak Mulia, City of Palembang. The research method used was completely randomized design (CRD) with 4 treatments and 3 replications. The results showed that treatment D (Extra Vitamin mix of $3 \%$ of total feed) was chosen as the best treatment than other treatments. At D treatment gives the best increase the growth and survival rate of the absolute length of $5,77 \mathrm{~cm}$ with a weight of $19.48 \mathrm{gram}$ and $S R$ values of $86,67 \%$. For treatment $C$ accretion absolute growth of $5.49 \mathrm{~cm}$ long with a weight of $17.64 \mathrm{gram}$ and SR values by $80 \%$. Treatment of B-added growth in the absolute length of 5,20 cm with a weight of 15,35 gram and SR values of $76.67 \%$. A treatment while providing the lowest growth increment is the absolute length of 5,01 cm with a weight of 15,03 gram and SR values of 76,67\%. Water quality parameters measured during the study are still within tolerable limits to grow and thrive Tilapia seed. From the results of research conducted for the addition of vitamins to the feed mix should use a dose of $3 \%$, as it gives the best growth and survival.
\end{abstract}

Keywords: Growth, Survival rate, nutrient content, Vitamin Mix 


\section{PENDAHULUAN}

Ikan Nila (Oreochromis niloticus) merupakan jenis ikan yang diintroduksi dari luar negri. Bibit ikan ini berasal dari Taiwan, dan didatangkan ke Indonesia secara resmi oleh Balai Penelitian Perikanan Air Tawar pada tahun 1969. Setelah melalui masa penelitian dan adaptasi, barulah ikan ini disebarluaskan kepada petani di seluruh Indonesia (Suyanto, 2002). Pemeliharaan Ikan Nila secara intensif (hanya mengandalkan pakan buatan) menunjukan keuntungan yag cukup tinggi. Namun demikian, agar hasil yang dharapkan lebih optimal, sebaiknya pakan yang diberikan harus memenuhi kebutuhan nutrisi yang baik. Zat-zat nutrisi yang dibutuhkan adalah protein, lemak, karbohidrat, vitamin, mineral, Karena pakan berpengaruh besar terhadap proses pertumbuhan dan kelangsungan hidup Ikan Nila (Sucipto dan Prihartono, 2005).

Pada proses pembuatan pakan ikan, kerusakan vitamin tidak dapat dihindarkan karena susutnya vitamin akibat oksidasi. Oksidasi ini disebabkan oleh pemanasan, penyimpanan yang terlalu lama (lebih dari 3 bulan), cahaya dan adanya kontak dengan udara. Vitamin harus ditambahkan kedalam pakan sebab tubuh ikan tidak mampu untuk membuatnya, maka penambahan vitamin sangat perlu untuk dilakukan (Afriyanto, 2005).

Penambahan vitamin kedalam pakan dilakukan dengan menggunakan vitamin mix (premix), karena kandungan vitamin yang lengkap pada vitamin mix sangat dibutuhkan bagi ikan untuk pertumbuhan, pemacu metabolisme dalam tubuh dan mendukung persentase sintasan. Seperti yang diungkapkan Hasinmoto (1970) dalam Samsudin dan Nainggolan, (2009) kekurangan satu atau lebih vitamin pada ikan dapat menyebabkan hilangnya nafsu makan, pertumbuhan lambat, dan mudah terserang penyakit. Dari hasil penelitian Samsudin dan Nainggolan, (2009) pemberian vitamin mix pada larva sidat menunjukan pengaruh yang baik terhadap pertumbuhan larva ikan sidat dengan dosis vitamin mix yang digunakan 2,5\% dari jumlah pakan.

\section{METODE PENELITIAN}

\section{Waktu dan Tempat Penelitian}

Pelaksanaan penelitian dilaksanakan Kelompok Tani Tambak Mulia Jln. Kapten Abdulah, Lorong Mulia 1, Rt.17, Rw.06 No.1168, Kelurahan Talang Bubuk, Plaju. Wadah yang digunakan untuk pemeliharaan Benih Ikan Nila adalah Bak plastik berukuran 40 × 30 × 25 $\mathrm{cm}^{3}$ sebanyak 12 unit. Sebelum digunakan bak dibersihkan terlebih dahulu, kemudian diisi air yang berasal dari air PDAM yang sudah diendapkan. Bak diisi air dengan volume 20 liter serta diberi aerasi.

\section{Metode Penelitian}

Penelitian ini mengunakan Rancangan Acak Lengkap (RAL) dengan 4 perlakuan dan 3 ulangan. Perlakuan berdasarkan perbedaan dosis vitamin mix dalam pakan. Perlakuan tersebut adalah sebagai berikut :

A : Tanpa perlakuan (Kontrol),

B : Penambahan Vit mix $1 \%$ dari jumlah pakan

C : Penambahan Vit mix $2 \%$ dari jumlah pakan

D : Penambahan Vit mix $3 \%$ dari jumlah pakan.

3. Analisis Data

\section{a. Pertumbuhan Berat}

Perhitungan pertambahan berat dan panjang Ikan Bawal (Colossoma macropomum) dilakukan seperti yang di kemukakan Effendie (1979) sebagai berikut :

$$
\mathbf{W}=\mathbf{W t}-\mathbf{W o}
$$

Keterangan :

$$
\begin{array}{ll}
\mathrm{W} & =\text { Pertambahan berat (gr) } \\
\mathrm{Wt} & =\text { Berat rata-rata ikan pada akhir }(\mathrm{gr}) \\
\mathrm{Wo} & =\text { Berat rata-rata ikan pada awal }(\mathrm{gr})
\end{array}
$$

\section{b. Pertumbuhan Panjang :}

$$
\mathbf{T}=\mathbf{L t}-\mathbf{L o}
$$

Keterangan :

$\mathrm{T}=$ Pertambahan panjang $(\mathrm{cm})$

$\mathrm{Lt}=$ Panjang rata-rata ikan pada akhir $(\mathrm{cm})$

Lo = Panjang rata-rata ikan pada awal $(\mathrm{cm})$

c. Kelangsungan Hidup (SR)

Pengamatan kelangsungan hidup Ikan Bawal (Colossoma macropomum ) menggunakan rumus yang dikemukakan Effendie (1979).

$$
\mathbf{S R}=\frac{\mathbf{N t}}{\mathbf{N}_{\mathrm{o}}} \times 100 \%
$$

Keterangan :

$$
\begin{array}{ll}
\mathrm{SR} & =\text { Derajat kelulusan hidup (\%) } \\
\mathrm{Nt} & =\text { Jumlah akhir pemeliharaan (ekor) } \\
\mathrm{No} & =\text { Jumlah pada awal penebaran (ekor) }
\end{array}
$$

d. Kualitas Air

Parameter kualitas air yang diukur meliputi suhu, $\mathrm{pH}$, oksigen terlarut (DO) dan $\mathrm{NH}_{3}$.

Data yang diperoleh dari hasil pengamatan selama penelitian akan dianalisis sidik ragam (ANOVA) pada taraf 5\% dan 1\% (Hanafiah, 1995).

\section{HASIL DAN PEMBAHASAN}

\section{Pertumbuhan Berat dan Panjang.}

Data hasil pertambahan panjang rata-rata Benih Ikan Nila (Oreochromis niloticus) selama penelitian dapat dilihat pada Tabel 1 berikut ini. 
Tabel 1.Pertambahan Panjang rata-rata (cm) Benih Ikan Nila (Oreochromis niloticus)

\begin{tabular}{ccccccc}
\hline Perlakuan Vitamin( \%) & \multicolumn{3}{c}{ Ulangan } & Jumlah & Rerata & \multirow{2}{*}{ BNT 0,05 } \\
\cline { 2 - 4 } & $\mathbf{1}$ & $\mathbf{2}$ & $\mathbf{3}$ & & & \\
\hline A & 5,20 & 4,60 & 5,23 & 15,03 & 5,01 & $\mathrm{a}$ \\
B & 5,03 & 5,44 & 5,12 & 15,59 & 5,20 & $\mathrm{a}$ \\
C & 5,56 & 5,47 & 5,43 & 16,46 & 5,49 & $\mathrm{a} \mathrm{b}$ \\
D & 5,97 & 6,00 & 5,34 & 17,31 & 5,77 & $\mathrm{~b}$ \\
\hline Total & & & & $\mathbf{6 4 , 3 9}$ & $\mathbf{5 , 3 7}$ & \\
\hline
\end{tabular}

Data hasil pertambahan berat rata-rata benih Ikan

Nila (Oreochromis niloticus) selama penelitian dapat dilihat pada Tabel 2.

Tabel 2. Pertambahan berat rata-rata (cm) Benih Ikan Nila (Oreochromis niloticus) selama penelitian.

\begin{tabular}{ccccccc}
\hline Perlakuan Vitamin ( \%) & \multicolumn{3}{c}{ Ulangan } & Jumlah & Rerata & \multirow{2}{*}{ BNT 0,05 } \\
\cline { 2 - 5 } & $\mathbf{1}$ & $\mathbf{2}$ & $\mathbf{3}$ & & & \\
\hline A & 16,03 & 14,46 & 14,59 & 45,08 & 15,03 & a \\
B & 15,9 & 14,26 & 15,88 & 46,04 & 15,35 & a \\
C & 18,63 & 16,73 & 17,55 & 52,91 & 17,64 & a b \\
D & 21,55 & 20,61 & 16,27 & 58,43 & 19,48 & b \\
\hline Total & & & & $\mathbf{2 0 2 , 4 6}$ & $\mathbf{1 6 , 8 7}$ & \\
\hline
\end{tabular}

Ket : huruf yang sama menunjukan perlakuan tidak berbeda nyata pada taraf $5 \%$

Berdasarkan hasil dari analisis sidik ragam (ANOVA) pada Tabel 1 dan Tabel 2 diatas, dapat dilihat bahwa penambahan Vitamin Mix pada pakan berpengaruh nyata terhadap pertumbuhan panjang dan berat pada benih Ikan Nila (Oreochromis niloticus). Hasil uji BNT menujukan rataan pertumbuhan panjang dan berat mutlak yang di beri penambahan vitamin mix 3 $\%$ (D) berbeda nyata pada taraf $5 \%$ dengan perlakuan lainya (A dan B). Penambahan vitamin mix pada pakan memberikan pertambahan pertumbuhan panjang mutlak terbaik pada perlakuan D yaitu sebesar $5,77 \mathrm{~cm}$ dibandingkan dengan perlakuan $\mathrm{C}$ pertambahan panjang mutlak sebesar 5,49 $\mathrm{cm}$ perlakuan B pertambahan panjang mutlak sebesar $5,20 \mathrm{~cm}$ dan terendah pada perlakuan $\mathrm{A}$ dengan pertambahan panjang mutlak sebesar $5,01 \mathrm{~cm}$.

Pertambahan berat mutlak benih Ikan Nila pada perlakuan D dengan (penambahan vitamin mix $3 \%$ dari jumlah pakan) memberikan nilai tertinggi sebesar 19,48 gr dibandingkan dengan perlakuan $\mathrm{C}$ (penambahan vitamin $2 \%$ dari

\begin{tabular}{ccccccc} 
Tabel 3. Rata-rata sintasan (\%) Benih Ikan Nila ( Oreochromis Niloticus) & selama Penelitian. \\
\cline { 1 - 4 } Perlakuan Vitamin (\%) & $\mathbf{1}$ & $\mathbf{2}$ & $\mathbf{3}$ & Jumlah & \multirow{2}{*}{ Rerata } \\
\cline { 2 - 4 } & 70 & 80 & 80 & 230 & 76,67 \\
A & 80 & 70 & 80 & 230 & 76,67 \\
B & 80 & 90 & 70 & 240 & 80 \\
C & 90 & 80 & 90 & 260 & 86,67 \\
D & & & & $\mathbf{9 6 0}$ & $\mathbf{8 0 , 0 0}$ \\
\hline Total & & &
\end{tabular}

Pada tabel 3. dapat dilihat bahwa nilai persentase Sintasan benih Ikan Nila pada penelitian ini menunjukan persentase yg cukup tinggi 70-86,67 \%. Dari hasil analisa sidik ragam (Lampiran 4) memperlihatkan penambahan vitamin mix tidak bebeda nyata terhadap sintasan benih Ikan Nila. jumlah pakan) berat mutlak benih Ikan Nila sebesar 17,64 gr, perlakuan B (penambahan vitamin $1 \%$ dari jumlah pakan) berat mutlak benih Ikan Nila sebesar 15,35 gr dan terendah pada pelakuan A (tanpa penambahan vitamin) berat mutlak benih Ikan Nila sebesar 15,03 gr. Hal ini diduga karena perlakuan D (penamaban vitamin mix $3 \%$ dari jumlah pakan) adanya kandungan vitamin $\mathrm{B}_{2}$ dan nicotinamide yang berfungsi menjaga nafsu makan ikan, membantu dalam produksi sel-sel darah, berpengaruh juga dalam sistem pencernaan, dan metabolisme tubuh dan kandungan vitamin $\mathrm{B}_{2}$ dan Nicotinamide dalam pakan yang jumlahnya lebih banyak dibandingkan perlakuan lainya seiring dengan peningkatan dosis perlakuan, menyebabkan terjadi peningkatan pertumbuhan panjang dan berat benih Ikan Nila.

\section{Kelangsungan Hidup}

Data hasil pengamatan rata-rata sintasan (\%) Benih Ikan Nila (Oreochromis Niloticus) selama penelitian dapat dilihat pada Tabel 3 berikut ini.

Tabel 3. Rata-rata sintasan (\%) Benih Ikan Nila (Oreochromis Niloticus) selama Penelitian.

Dari keempat perlakuan (A, B, C, dan D) tidak memberikan rataan sintasan yang berbeda, namun pada (tabel 6) rata-rata sintasan, pada perlakuan D di pilih sebagai perlakuan terbaik menunjukan persentase sintasan yaitu 86,67\%, Menurut SNI (2000), tingkat persentase sintasan Ikan Nila sebesar $70 \%-80 \%$ menunjukkan tingkat persentase sintasan yang baik. Hal ini 
disebabkan karena pada perlakuan D, dosis vitamin mix lebih banyak dibandingkan dengan perlakuan B dan C. diduga kandungan vitamin $\mathrm{C}$ yang ada didalam vitamin mix dapat mempengaruhi ketahanan tubuh pada ikan, sehingga ikan dapat bertahan dari kondisi stress. Kondisi stres pada benih Ikan Nila diduga karena terjadi kepadatan pada minggu ke-5 yaitu ukuran ikan sudah memasuki tahap pembesaran yang seharusnya padat tebar ikan pada wadah pemeliharaan harus disesuaikan dengan ukuran ikan.

Menurut Tucker dan Halver (1984) dalam Sunarto et al (2008), vitamin C pada pakan befungsi meningkatan ketahanan tubuh, mengatasi stres dan mempertahan kan kondisi tubuh. Didukung oleh pendapat Masumoto (1991) dalam Firdaus (2004), vitamin C Tabel 4. Data Parameter kualitas air selama pemeliharaa.

\begin{tabular}{ccccc}
\hline \multirow{2}{*}{ Perlakuan } & \multicolumn{5}{c}{ Parameter } \\
\cline { 2 - 5 } & Suhu $\left({ }^{\mathbf{0}} \mathbf{C}\right)$ & $\mathbf{p H}$ & $\mathbf{D O}(\mathbf{m g} / \mathbf{L})$ & Amonia $(\mathbf{m g} / \mathbf{L})$ \\
\hline A & $26-28$ & $6,7-6,9$ & $2,94-3,40$ & $0,012-0,014$ \\
B & $26-28$ & $6,8-6,9$ & $3,45-3,90$ & $0,003-0,012$ \\
C & $26-28$ & $6,7-6,8$ & $3,15-3,74$ & $0,013-0,016$ \\
D & $26-28$ & $6,8-7,0$ & $3,36-3,98$ & $0,009-0,014$ \\
\hline Kisaran Toleransi & $\mathbf{2 5 - 3 5 *}$ & $\mathbf{6 , 5 - 7 , 5 * *}$ & $>\mathbf{2}^{* *}$ & $<\mathbf{0 1 0} *$ \\
\hline
\end{tabular}

Keterangan : * Sucipto dan Hartono (2005) ** Soetomo (2000)
Pada Tabel 4 diatas menunjukkan parameter kualitas air yang diukur selama penelitian masih dalam batas toleransi untuk tumbuh dan berkembang benih Ikan Nila. Kisaran suhu selama penelitian adalah $26-28{ }^{\circ} \mathrm{C}$ masih cukup baik untuk pertumbuhan Ikan Nila, selama penelitian suhu dalam keadaan yang sama, dikarenakan penelitian dilakukan secara homogen dan di lakukan diindor.

Menurut Sucipto dan Prihartono (2005) suhu optimal untuk Ikan Nila antara $25-35{ }^{\circ} \mathrm{C}$. Nafsu makan ikan akan dapat terganggu bila suhu air berada dibawah $16-17{ }^{\circ} \mathrm{C}$. Saat pemeliharaan, pH pada media pemeliharaan masih dalam batas toleransi dengan kisaran 6,7-7 untuk pertumbuhan benih Ikan Nila. Hal ini sesuai dengan pendapat Swingle (1961) dalam Soetomo (2000) yang mengatakan bahwa pH antara 6,57,5 baik untuk budidaya Ikan Nila. Konsentrasi oksigen terlarut selama penelitian berfluktuatif dengan kisaran 2,94-3,98 mg/L. Menurut Soetomo (2000), kandungan oksigen terlarut untuk pertumbuhan Ikan Nila adalah diatas 2 $\mathrm{mg} / \mathrm{L}$. Amonia media pemeliharaan selama penelitian berkisar 0,003-0,014 mg/L. Kandungan tersebut masih layak untuk pertumbuhan ikan dikarenakan pada saat penelitian setiap hari dilakukan penyiponan agar kadar amonia dalam air rendah. Hal ini sesuai dengan pendapat Soetomo (2000) yang mengatakan bahwa kadar berfungsi untuk mempertahankan proses fisiologi ikan, kemampuan tubuh untuk menghadapi stress dan meningkatkan imunitas terhadap penyakit. Persentase sintasan terendah terdapat pada perlakuan A (Tanpa perlakuan) sebesar 76,67 \%, hal ini diduga karena pada pakan tidak ditambahkan vitamin mix, dimana pada vitamin mix terdapat vitamin $\mathrm{C}$ yang berfungsi untuk menambah ketahanan tubuh, dan mengatasi strees. kekurangan vitamin $\mathrm{C}$ pada ikan akan menyebabkan ketahanan tubuh ikan akan menurun sehingga ikan cepat stress maupun mudah terserang penyakit.

\section{Kualitas Air}

Kisaran data parameter kualitas air melputi suhu, pH, oksigen terlarut (DO), dan amoniak selama pemeliharaan dapat dilihat pada Tabel 4. amoniak yang lebih baik untuk kehidupan ikan dan organisme perairan lainnya adalah tidak lebih dari $0,01 \mathrm{mg} / \mathrm{L}$.

\section{KESIMPULAN DAN SARAN}

\section{Kesimpulan}

Dari hasil penelitian yang telah dilakukan dapat disimpulkan bahwa perlakuan D (penambahan vitamin mix $3 \%$ dari jumlah pakan) memberikan hasil terbaik untuk pertumbuhan dan sintasan benih Ikan Nila dibandingkan perlakuan lainnya, hal ini dapat dilihat dari tingkat sintasan sebesar 86,67\% dengan rata-rata pertambahan panjang mutlak sebesar $5,77 \mathrm{~cm}$ dan pertambahan berat mutlak sebesar 19,48 gram.

\section{Saran}

1. Untuk mempercepat pertumbuhan benih Ikan Nila (Oreochromis niloticus) dapat dilakukan penambahan vitamin mix sebesar $3 \%$ dari jumlah pakan.

2. Perlu dilakukan uji lanjut untuk menentukan dosis penambahan vitamin mix yang optimal guna mempercepat pertumbuhan Ikan Nila. 


\section{DAFTAR PUSTAKA}

Afrianto, E. 2005. Pakan Ikan. Kanisius. Yogyakarta.

Effendie,M.I. 1997. Metode Biologi Perikanan. Yayasan Dewi Sri. Bogor.

Firdaus, A. 2004. Pengaruh Pemberian Vitamin C dalam Percobaan Immunoprofilaksis Terhadap Infeksi Bakteri Stereptococcus iniae Pada Ikan Nila. Fakultas Perikanan dan Ilmu Kelautan. IPB. Bogor.

Handajani. 2010. Optimalisasi Substitusi Teping Azolla Terfermentasi Pada Pakan Ikan Untuk Meningkatkan Produktifitas Ikan Nila Gift. Jurusan Perikanan. Universitas Muhammadiyah Malang.

Ikhwan dan Adelina. 2009. Pengaruh vitamin c terhadap peningkatan hemoglobin $(\mathrm{Hb})$ darah dan kelulusan benih ikan kerapu bebek (Cromileptes altiveles). Fakultas Perikanan dan Ilmu Kelautan. Universitas Riau. Pekan Baru.
Sunarto, 2008. Sumplementasi Vitamin C Dalam Untuk Memacu Perkembangan Gonad Dan Meningkatkan Mutu Telur Ikan Kerapu Batik. Thesis. Program Pasca sarjana. IPB. Bogor.

Sendjaja, JT. 2002. Pembenihan Nila. Jakarta: Penebar Swadaya

Samsudin dan Nainggolan. 2009. Efek penambahan vitamin pada pakan buatan terhadap pertumbuhan larva dan perkembangan sidat, Anguilla bicolor bicolor. Fakultas Perikanan. Universitas Satya Negara Indonesia. Jakarta.

Suyanto. 2003. Nila. Penebar Swadaya. Bogor.

Soetomo. 2000. Penggunaan berbagai binder rumput laut pada pakan ikan terhadap respon biologis Ikan Nila. Politeknik Pertanian Negeri Pangkep. Makasar.

Sucipto dan Prihartono. 2005. Pembesaran Nila Merah Bangkok. Penebar Swadaya. Jakarta. 
Jurnal Ilmu-ilmu Perikanan dan Budidaya Perairan Volume 14, Nomor 2, Desember 2019 